\title{
Perception of cancer patients in palliative care about quality of life
}

\author{
Percepção de pacientes oncológicos em cuidados paliativos sobre qualidade de vida \\ Percepción de los pacientes con cáncer en cuidados paliativos en la calidad de vida
}

\section{Silmara Meneguin', Ticiane Dionísio de Sousa Matos', Maria de Lourdes da Silva Marques Ferreira' \\ ' Universidade Estadual Paulista Júlio de Mesquita Filho, Botucatu Medical School. Botucatu, São Paulo, Brazil.}

\section{How to cite this article:}

Meneguin S, Matos TDS, Ferreira MLSM. Perception of cancer patients in palliative care about quality of life. Rev Bras Enferm [Internet]. 2018;71(4):1998-2004. DOI: http://dx.doi.org/10.1590/0034-7167-2017-0360

Submission: 05-30-2017_Approval: 09-14-2017

\begin{abstract}
Objective: To understand the perception of cancer patients in palliative care about quality of life and identify propositions for its improvement. Method: This is a quantitative research carried out with 96 patients in palliative care, admitted in a public hospital from March 2015 to February 2015. The interviews were transcribed and analyzed by the methodology Discourse of the Collective Subject. Results: Quality of life was tied to meanings of health, well-being, happiness and spirituality; however, family and financial problems also had an impact on the perception of the construct. Interventions aimed at the relief of suffering, possibility of return to work and resolution of problems had suggestions for improvement. Conclusion: The results indicate that the concept of quality of life is subjective, tied to personal values and influenced by the repercussions of the health-disease process. In addition, they can guide actions based on interdisciplinary assistance aimed at the real needs of these patients.
\end{abstract}

Descriptors: Quality of Life; Oncology; Palliative Care; Nursing; Ambulatory Care.

\section{RESUMO}

Objetivo: Compreender a percepção de pacientes oncológicos em cuidados paliativos em relação a qualidade de vida e identificar proposições para melhoria desta. Método: Pesquisa qualiquantitativa realizada com 96 pacientes em cuidados paliativos, atendidos em ambulatório de hospital público, no período de março de 2015 a fevereiro de 2016. As entrevistas foram transcritas e analisadas pela estratégia metodológica do Discurso do Sujeito Coletivo. Resultados: Qualidade de vida foi atrelada a significados de saúde, bem-estar, felicidade e espiritualidade; porém problemas familiares e financeiros também repercutiram na percepção do constructo. Teve como sugestões de melhoria intervenções direcionadas ao alívio do sofrimento, possibilidade de retorno ao trabalho e resolubilidade de problemas. Conclusão: Os resultados do estudo indicam que a concepção de qualidade de vida é subjetiva, atrelada a valores pessoais e influenciada pelas repercussões do processo saúde-doença. Além disso, podem nortear ações pautadas numa prática assistencial interdisciplinar, direcionada às reais necessidades destes pacientes.

Descritores: Qualidade de Vida; Oncologia; Cuidados Paliativos; Enfermagem; Assistência Ambulatorial.

\section{RESUMEN}

Objetivo: Comprender la percepción de pacientes oncológicos en cuidados paliativos en relación a la calidad de vida e identificar proposiciones para su mejora. Método: Investigación cualitativa y cuantitativa realizada con 96 pacientes en cuidados paliativos, atendidos en ambulatorio de hospital público, en el período de marzo de 2015 a febrero de 2016. Las entrevistas fueron transcritas y analizadas por la estrategia metodológica del Discurso del Sujeto Colectivo. Resultados: La calidad de vida se ha vinculado a significados de salud, bienestar, felicidad y espiritualidad; pero problemas familiares y financieros también repercutieron en la percepción del constructo. Para mejora de intervenciones dirigidas al alivio del sufrimiento, se sugirió la posibilidad de retorno al trabajo y resolución de problemas. Conclusión: Los resultados del estudio indican que la concepción de calidad de vida es subjetiva, vinculada a valores personales e influenciada por las repercusiones del proceso salud-enfermedad. Además, pueden guiar acciones pautadas en una práctica asistencial interdisciplinaria, dirigida a las reales necesidades de estos pacientes.

Descriptores: Calidad de Vida; Oncología Médica; Cuidados Paliativos; Enfermería; Atención Ambulatoria.

\section{CORRESPONDING AUTHOR Silmara Meneguin E-mail: silmeneguin@fmb.unesp}




\section{INTRODUCTION}

Palliative care in oncology is necessary when the incurability becomes a reality before the inefficiency of curative treatment and disease progression ${ }^{(1)}$. At this stage, the assessment of quality of life becomes critical, since the search for it in all its nuances, and even to the detriment of the prolongation of life, becomes very important.

Care in the context of palliative assistance differs from curative care because it reaffirms life and faces death as a reality to be experienced with relatives. In such a situation, care has the premise of improving the quality of life of patients and their families before an advanced illness by the prevention and relief of suffering and the appreciation of culture, spirituality, and beliefs and values that permeate the "terminality"(2-3).

The quality of life has been defined by the World Health Organization (WHO) "as an individual's perception of their position in life in the context of the culture and value systems in which they live and in relation to their goals, expectations, standards and concerns" ${ }^{\prime \prime)}$. In health, quality of life is related to the impact of diseases and treatments that influence it ${ }^{(5)}$.

However, assessing quality of life - a subjective and abstract construction - is admittedly a complex task. The definition adopted by the WHO is complex and demonstrates the positive and negative aspects of life. This is a multidimensional concept that deals with the relationship between environment and physiopsychological aspects of the individual, level of independence, social relationships and personal beliefs ${ }^{(6)}$. Nevertheless, three aspects are common to all definitions: subjectivity, dimensionality and bipolarity ${ }^{(7)}$.

Assuming that both the cancer as its treatment may adversely influence the perception of quality of life, the latter is still considered a critical measure in oncology ${ }^{(8)}$. The diagnosis of cancer brings major changes in the way of living, with emotional and physical changes caused by the discomfort, pain, disfigurement, dependency and loss of self-esteem. In addition, cancer carries the stigma and the condition of finiteness before a disease considered for many people without the possibility of cure. Furthermore, it is known that over $50 \%$ of cancer patients present five common symptoms that may interfere with the perception of quality of life: fatigue, weakness, pain, weight loss and anorexia(9).

Thereby, the assessment of quality of life has been an indicator to guide assistance practices and assist in defining public policy strategies, considering that conditionings and determinants factors of health-disease process are multifactorial and complex.

Recent data from systematic review showed that physical skills, personal autonomy, emotional, social, spiritual, and cognitive state, as well as health care and preparation for death are important aspects of quality of life for people with diseases without prospects for cure ${ }^{(10)}$. However, the refinement of measures of quality of life for patients in palliative care proved to be necessary to identify issues valued by the patients, as a preparation for death and aspects inherent to the health care delivery, which are often not referred in the quality-of-life instruments available in the literature ${ }^{(11)}$.

Thus, this study seeks to enhance the uniqueness of the individual with terminal cancer, contributing to the construction of knowledge in the area of palliative care from the experiences of cancer patients. This study aimed to answer the following guiding question: what is the meaning that cancer patients in palliative care assign to their quality of life?

\section{OBJECTIVE}

To understand the perception of cancer patients in palliative care about quality of life and identify propositions for its improvement.

\section{METHOD}

\section{Ethical aspects}

The research was approved by the Research Ethics Committee of the Faculty of Medicine of Botucatu and obtained Informed Consent Form (ICF) from all participants, according to the Resolution no. $466 / 12^{(12)}$.

\section{Theoretical-methodological framework and type of study}

This is quantitative research, which used the technique Discourse of the Collective Subject, based on the theory of social representations ${ }^{(13)}$.

\section{Study scenario and social actors}

The study was carried out in a palliative care unit of a public university from the city of Botucatu, SP, Brazil. This unit receives only cancer patients, with all kinds of neoplasia and in advanced stage of the disease.

Patients in outpatient care, of both sexes, aged 18 years or over, and who agreed to participate in the research were considered eligible for the study. Participants who declared not having emotional conditions to participate/continue in the interview were excluded. Finally, blood relatedness was considered "direct kinship" and marriage, "indirect kinship".

A sample was comprised of 96 patients admitted in the palliative care unit of the institution abovementioned from March 2015 to February 2016. This sample corresponded to the total number of patients seen in the period of data collection. There was no refusal of patients to participate in the interview or interruption. The researchers were composed of two professors with $\mathrm{PhD}$ degree and an undergraduate student, all without any kind of link with the participants.

The information about the researchers, transmitted to the patients when they were invited to participate in the research, were presented in the ICF. The transcripts of the interviews could not be returned to the participants for comments.

\section{Data source}

We collected data through semi-structured interviews, using an instrument with demographic data and the following guiding questions: "In your opinion, what it means to have quality of life?"; "In your perception, what has interfered in your quality of life in the last days?"; "How your quality of life could be improved, according to you?".

Only data inherent in the neoplasia were obtained by consulting the medical chart, the other data, such as sex, religion, among others, were obtained by interviewing the participants. 
The interviews were audio-recorded individually and conducted in private environment, prior medical consultation, by one of the researchers with training in data collection technique.

\section{Data analysis}

Interviews were transcribed and subjected to manual analysis by one of the researchers with experience in operating the methodological strategy Discourse of the Collective Subject ${ }^{(13)}$. The methodological steps of this technique, followed from the interviews until the synthesis of speeches, included:

- Reading the reports collected in the interviews;

- Reading the response to each question in private, marking the key expressions selected;

- Identifying the central ideas of each response;

- Analyzing the key expressions and ideas, by grouping the similarities in homogeneous sets;

- To identify and nominate the central idea of the homogenous set, which will be a summary of the central ideas of each speech;

- To construct the discourse of the collective subject after identifying the central ideas and key expressions that nominated these speeches.

\section{RESULTS}

Regarding the characterization of the participants, we found that most were female $(60.4 \%)$, catholic $(69.8 \%)$, and with companion $(61.5 \%)$. Of all participants, $63.5 \%$ attended only elementary school, $57.3 \%$ lived with blood relatives and $82.3 \%$ were practitioners of any religion.

Among the neoplasms, breast cancer prevailed in $32.3 \%$ of participants, followed by gastrointestinal cancer $(17.7 \%)$, testicular cancer (10.4\%) and lymphoma (10.4\%), and $29.2 \%$ corresponded to other neoplasms. Of the total, about $40 \%$ were metastatic tumors.

From the analysis of the transcript of the interviews, we identified the key expressions and the main ideas, in addition to build the speeches of the three themes, which emerged from the guiding questions.

\section{Theme 1 - Perception of cancer patients in palliative care about quality of life}

Main ideas:

A - Good health

B - Good nutrition

$\mathrm{C}$ - Living in peace

D - Having God in my life

E - Be happy

\section{Discourse of the Collective Subject}

For me, quality of life means to be in good health, because in good health we can do anything. When we can feed ourselves and our table is full of food, this also improves a lot our quality of life. Another very important point is to live in peace with my family and be happy. Be physically fit and feel good with me and the people around me, it's all part. The most important thing is to have God in our hearts, because He gives us the strength to move on and He also does miracles in our lives. When I go to church praise to our Lord, I change, I become very happy and my quality of life also changes. Quality of life is to live in peace with my husband, to have a good relationship, to respect each other and to live in harmony with my family. Finally, for me, quality of life is to live in peace, have a table full of food, be with my family, be good to myself and be happy.

Theme 2 - Factors that interfered in the perception of terminally ill patients in palliative care about quality of life

Main ideas:

A - Lack of family support

B - Pain

C - Treatment symptoms

D - Fear of death

E - The disease itself

$\mathrm{F}$ - Inability to feed herself/himself

G - Financial distress

Discourse of the Collective Subject

Not having the support of my family and especially my husband made my life much worse, not to mention the fact of being abandoned by people so close, which made me very upset. In addition to all this suffering caused by the lack of family support, there is also this horrible pain. The pain bothers me and prevents me from doing my daily activities. Besides, the symptoms that I have when I do the treatment make my quality of life much worse. This disease is horrible, the fear and the strain in this period are very big. This disease maltreated us so much, only God gives me strength, I'm so afraid that I couldn't beat it. And to make matters worse, because of the symptoms, I end up having no appetite, and when I have, I can't eat, even if I'm very hungry, because often only the smell of the food makes me sick, causing discomfort. In addition to all this, we still have to face the lack of money for basic things in the house.

Theme 3 - Contributions that would improve the quality of life of patients in palliative care

Main ideas:

A - Do not have the disease

$B$ - Do not feel pain

C - To feed herself/himself

D - To return to work

E - To have a good financial condition

$\mathrm{F}$ - To relief the suffering

Discourse of the Collective Subject

My quality of life could be improved if I was cured, with no more pain, and if I didn't have to spend more with this treatment, being able to live my life without worrying about medical appointments and anything, just with the maintenance of the house. Be able to sit at the table and eat with 
my family, without feeling bad, taste a good plate of food and enjoy my family. My quality of life would be perfect if my health was restored. With my health recovered I would go back to work and get my family's livelihood with dignity. Get rid of this disease and not to suffer anymore mean a new beginning and a better quality of life. To give a good life for my family and be happy. No more pain, no one deserves to go through so much pain.

\section{DISCUSSION}

To assess the quality of life in palliative care has been a challenge because the psychometric instruments available in the literature for measurement of the construct not always can assimilate the values of the individuals and their real needs before the great effects imposed by the disease.

In this research, the relationship between health and quality of life became evident when the participants referred to the pain in the final stage of the disease, confirming the close analogy of the construct with the perception of physical well-being - data confirmed by recent studies on patients with advanced cancer who had the quality of life affected by the severity of the disease and the diversity of symptoms ${ }^{(14-15)}$.

For patients with advanced cancer, the discussion about the prognosis and the integration with palliative care may positively impact the quality of life, since the proposed treatments do not always contribute to relieve symptoms and prevent the progression of the disease, as shown in literature ${ }^{(16)}$. In addition, it must be considered that the progression of the disease contributes to worsen the quality of life, as evidenced in randomized study carried out with 733 patients with advanced or metastatic lung cancer submitted to different treatments ${ }^{(17)}$.

On the other hand, we must consider in this study that possibly not all participants were aware of the palliative character of their monitoring in the institution where the research was conducted. It is still common in Brazil the referral of patients for palliative assistance without clarification about diagnosis and treatment, which may have influenced the results of the research.

Palliative care does not refer to the failure of interventions in health, but are a different care approach, which aims to improve the quality of life of patients and their families by relieving pain and suffering and by controlling signs and symptoms, together with psychosocial and spiritual support ${ }^{(2,18)}$.

The lack of family support was mentioned by some participants, as evidenced in the discourse of the collective subject - a fact that may be related to the social characteristics of the participants of the study. However, the literature has shown that family members are often the main source of social and emotional support to patients because they play an important role in the health-disease process. Recent study that assessed the quality of life of cancer patients in different periods of treatment showed that the quality of life was positively correlated with the social support offered ${ }^{(19)}$.

On the other hand, the perception of being a burden to the family is a major concern for patients with advanced cancer, not only by the costs imposed by the disease, but also by the care provided that influence on perception, sense of helplessness etc ${ }^{(20)}$.

Study conducted with 1,271 caregivers of cancer patients in Italy showed that while families are responsible for a small portion of all costs arising from care at home, the impact of the disease on daily life activities and family savings can be substantial(21). Another study conducted with Brazilian caregivers identified that cancer can be responsible for the financial slope of many families, as many patients and caregivers contribute to the family income and leave work after the diagnosis of the disease ${ }^{(22)}$. Furthermore, we must consider the moral obligation imposed on family to take care of the terminally ill patient, without proper training or qualification for exercising this function, exposing the vulnerability of the individual who is in front of the complex interfaces that permeate the dynamics of care in these circumstances ${ }^{(23)}$.

Before the challenge of taking care of end-of-life patients, it is necessary to expand the understanding of the human being beyond the biological dimension, to understand the suffering mentioned by participants, which may appear in any dimension of life, since it is integrated by the meaning and the sense associated to $\mathrm{it}^{(24)}$.

In this context, religion and spirituality are often adopted to deal with the stress and suffering generated by the cancer, because for many patients these constructs can contribute to the relief of suffering before the moment in which they find themselves, providing strength to continue living and contributing, therefore, to improve the quality of life, as revealed by the participants in the first theme. In addition, the study identified that, at times, patients sought religion/spirituality to provide hope, faith in healing, and return to health.

Although distinct, religion and spirituality are intimately intertwined. Spirituality is considered the essence of a person, as a search for meaning and purpose to life. In addition to be considered a protective measure, it is defined as unique, personal and dynamic, and may change according to individual perception and moments of life. It is linked to relationship with God or a higher being and to the person's relationship with herself/ himself and with others ${ }^{(25)}$. Religiosity, in turn, is the expression of spirituality itself through rituals, dogmas and doctrines ${ }^{(26)}$.

Thereby, many patients in palliative care seek religion/spirituality as support to provide hope, faith in healing and return to good health. The relationship between religiosity and palliative care have increasingly been investigated, and the evidence points to a positive relationship, for the most part. Studies show that religiosity and spirituality improve the quality of life, in addition to decrease the stress and depression ${ }^{(27-28)}$.

In another study, conducted with 30 Icelanders patients, the quality of life was positively correlated to spiritual well-being ${ }^{(29)}$. Recent comprehensive review also identified that spiritual dimension is an essential component of palliative care to the patient, because it promotes well-being through relief of pain and other symptoms ${ }^{(30)}$.

Although it does not prevent problems to happen in people's lives, religion represents a resource at the time of difficulty, assigning meanings to events and providing tools to face suffering $^{(31)}$. Despite the recognized importance of religious/spiritual support, in the institution where the research was conducted there is no such support for patients.

A study conducted in Spain, with patients and caregivers of a spiritual care unit, showed that spiritual care help patients to have hope $(88 \%)$, comfort $(83 \%)$, to find meaning $(79.1 \%)$ and understand sense $(73.4 \%)$. To $92.5 \%$ of participants the spiritual 
attention is required during this period, because it improves the quality of life and the process of confrontation with death ${ }^{(32)}$.

To think about death means to reflect about its power, because it breaks links, disrupts dreams and imposes the obligation to rethink life, values and emotions. The fear of death and/or the process of dying is linked to the abolition of the being, working at the same time as a restorer and a multiplier of other fears that can impact the quality of life ${ }^{(33)}$.

Beyond that, before the prospect of finitude, people are valuing other aspects of life. This fact can be ratified in the reports of the third theme, when participants express desire for good health, relieving the suffering, feeding themselves etc. - data that shows that quality of life is often based on satisfaction of basic human needs.

\section{Study limitations}

One of the limitations of the research is related to the fact of having been developed in a single health unit, with local particularities that restrict the results to a single institution. We believe that it would be appropriate the comparison with other units, mainly specialized cancer units, but such comparison was not possible because the city does not own a hospital for this specialty. In addition, we must consider the heterogeneity of the participants regarding the type of cancer and the clinical condition.

Contributions to the field of nursing, health, or public policies

We expected that the results of this study contribute to guide the learning of health professionals facing the patient without possibilities of cure, allowing the approach of their experiences and the understanding of their suffering and their real needs to promote quality of life.

In addition, the research offers subsidies to health professionals so that care strategies are targeted to actions based on interdisciplinary assistance, considering the real needs of the patients, that often go unnoticed. These actions would bring to patients the possibility of full and continuous care, focusing on relieving their biopsychosocial and spiritual needs.

\section{FINAL CONSIDERATIONS}

The results reflect the perception of cancer patients in palliative care about quality of life, as well as the difficulties and suffering experienced in this period of extreme vulnerability. The results indicate that the concept of quality of life is subjective, tied to personal values and influenced by the repercussions of the health-disease process. In addition, the report of the patients gave visibility to family issues and financial impacts on the perception of the construct. The suggestions for improving the quality of life according to the respondents were based on interventions aimed at relieving the suffering, returning to work, resolution of financial problems and possibility of oral feeding.

\section{FUNDING}

Fundação de Amparo à Pesquisa do Estado de São Paulo (FAPESP).

\section{REFERENCES}

1. Conselho Regional de Medicina do Estado de São Paulo. Cuidados paliativos. In: Maciel MGS. Definições e princípios [Internet]. 2008 [cited 2017 Jul 09]. Available from: http://www.cremesp.org.br/library/modulos/publicacoes/pdf/livro_cuidado\%20paliativo.pdf

2. Mi-Kyung S, Mary BH. Generating high quality evidence in palliative and end-of-life care. Heart Lung [Internet]. 2017 [cited 2017 Feb 28];46(1):1-2. Available from: http://www.heartandlung.org/article/S0147-9563(16)30341-7/pdf

3. World Health Organization-WHO. Definition of Palliative Care [Internet]. 2010 [cited 07 Jul 2017]. Available from: http://www. who.int/cancer/palliative/definition/en/

4. World Health Organization-WHOQOL: measuring quality of life. Introducing the WHOQOL instruments [Internet]. 2017[cited 2017 Jul 07]. Available from: http://www.who.int/mental_health/publications/whoqol/en/

5. Romero M, Vivas-Consuelo D, Alves- Guzman N. Is Health Related Quality of Life (HRQoL) a valid indicator for health systems evaluation? Springer Plus [Internet]. 2013 [cited 2017 Mar 10];2(1):664-70. Available from: https://www.ncbi.nlm. nih.gov/pmc/ articles/PMC3866375/

6. Minayo MCS, Hartz ZMA, Buss PM. Qualidade de vida e saúde: um debate necessário. Ciênc Saúde Colet[Internet]. 2000 [cited 2017 Jul 09];5(1):7-18. Available from: http://www.scielo.br/pdf/csc/v5n1/7075.pdf

7. Sawada NO, Nicolussi AC, Paula JM, Garcia-Caro MP, Marti-Garcia C, Cruz-Quintana F. Quality of life of Brazilian and Spanish cancer patients undergoing chemotherapy: an integrative literature review. Rev Latino-Am Enfermagem [Internet]. 2016 [cited 2017 May 09];24:e2688. Available from: http://www.scielo.br/pdf/rlae/v24/0104-1169-rlae-24-02688.pdf

8. Holmenlund K, Sjøgren P, Nordly M. Specialized palliative care in advanced cancer: what is the efficacy? a systematic review. Palliat Supp Care [Internet]. 2017 [cited 2017 Jul 09];13:1-17. Available from: https://www.researchgate. net/publication/317568857

9. Teunissen SCCM, Wesker W, Kruitwagen C, Hanneke CJM, Voest EE, Graeff A. Symptom prevalence in patients with incurable cancer: a systematic review. J Pain Symptom Manag[Internet]. 2007 [cited 2017 Feb 28];34(1):94-104. Available from: http://www. sciencedirect.com/science/article/pii/S0885392407002011

10. Catania G, Beccaro M, Costantini M, Timmis F, Zanini M, Aleo G, et al. What are the components of interventions focused on qualityof-life assessment in palliative care practice? a systematic review. J Hosp Palliative Nurs[Internet]. 2016[cited 2017 Feb 28];18(4):310-6. Available from: http://journals.Iww.com/jhpn/Abstract/2016/08000/What_Are_the_Components_of_Interventions_Focused.8.aspx 
11. McCaffrey N, Bradley S, Ratcliffe J, Currow DC. What aspects of quality of life are important from palliative care patients' perspectives? a systematic review of qualitative research. J Pain Symptom Manage [Internet]. 2016 [cited 2016 sept 12];52(2):318-28. Available from: https://www.ncbi.nlm.nih.gov/pubmed/27216362

12. Brasil. Conselho Nacional de Saúde. Resolução № 466, de 12 de dezembro de 2012[Internet]. Aprova as diretrizes e normas regulamentadoras de pesquisas envolvendo seres humanos. Diário Oficial da União. 12 dez 2012 [cited 2017 Feb 10]. Available from: http://bvsms.saude.gov.br/bvs/saudelegis/cns/2013/res0466_12_12_2012.html

13. Lefevre F, Lefevre AMC. O Discurso do Sujeito Coletivo: um novo enfoque em pesquisa qualitativa. Caxias do Sul (RS): Educs; 2003.

14. Oliveira PI, Pereira CAC, Belasco AGS, Bettencourt ARC. Comparison of the quality of life among persons with lung cancer, before and after the chemotherapy treatment. Rev Latino-Am Enfermagem [Internet]. 2013 [cited 2017 Feb 28];21(3):787-94. Available from: http://www.scielo.br/pdf/rlae/v21n3/0104-1169-rlae-21-03-0787.pdf

15. Augustussen M, Sjøgren P, Timm H, Hounsgaard L, Pedersen ML. Symptoms and health-related quality of life in patients with advanced cancer: a population-based study in Greenland. Eur J Oncol Nurs [Internet]. 2017[cited 2017 Jul 07];28:92-7. Available from: http://www.sciencedirect.com/science/article/pii/S1462388917300157

16. Dulaney C, Wallace AS, Everett AS, Dover L, McDonald A, Kropp L. Defining health across the cancer continuum. Cureus [Internet]. 2017 [cited 2017 Feb 28];9(2):e1029. Available from: https://www.ncbi.nlm.nih.gov/pmc/articles/PMC5354402/pdf/ cureus-0009-0000000 1029.pdf

17. Twelves C, Cortés J, O'Shaughnessy J, Awada A, Perez EA, Im SA, et al. Health-related quality of life in patients with locally recurrent or metastatic breast cancer treated with etirinotecan pegol versus treatment of physician's choice: results from the randomised phase III BEACON trial. Eur J Cancer [Internet]. 2017 [cited May 09];76:205-15. Available from: http://www.sciencedirect.com/ science/article/pii/S0959804917307360

18. National Consensus Project for Quality Palliative Care. Clinical practice guidelines for quality palliative care [Internet]. 2009 [cited 2016 Jun 20]. available from: https://www.hpna.org/multimedia/NCP_Clinical_Practice_Guidelines_3rd_Edition.pdf

19. Yang L, Song WP, Chen ZL, Wang Y, Chen YY, Hua YH, et al. Correlation between social support and quality of life in patients with breast cancer at different periods of treatment. Zhonghua Zhong Li Za Zhi [Internet]. 2017 [cited 2017 May 09];39(3):202-6. Available from: https://www.ncbi.nlm.nih.gov/pubmed/28316220

20. Adorno G, Wallace C. Preparation for the end of life and life completion during late-stage lung cancer: an exploratory analysis. Palliat Supp Care [Internet]. 2017 [cited 2017 May 09];18:1-11. Available from: https://www.ncbi.nlm.nih.gov/pubmed/28095941

21. Rossi PG, Beccaro M, Miccinesi G, Borgia P, Costantini M, Chini F, et al. Dying of cancer in Italy: impact on family and caregiver. The Italian Survey of Dying of Cancer. J Epdidemiol Community Health [Internet]. 2007 [cited 2017 Feb 28];61(6):547-54. Available from: https://www.ncbi.nlm.nih.gov/pmc/articles/PMC2465721/

22. Araújo LZS, Araújo CZS, Souto AKBA, Oliveira MS. Cuidador principal de paciente oncológico for a de possibilidade de cura, repercussões deste encargo. Rev Bras Enferm [Internet]. 2009 [cited 2017 May 10];62(1):32-7. Available from: http://www.scielo. $\mathrm{br} / \mathrm{pdf} / \mathrm{reben/v62n1/05.pdf}$

23. MacLeod A, Skinner MW, Low E. Supporting hospice volunteers and caregivers through community-based participatory research. Health Soc Care Community [Internet]. 2012 [cited 2017 Feb 28];20(2):190-8. Available from: https://www.ncbi.nlm.nih.gov/ pubmed/21978371

24. Montoro CH, González JS, Siles J, Amezcua M, Nieves CB, Montero SP, et al. Understanding the suffering of a patient with an illness: signs, context and strategies. Rev Latino-Am Enfermagem [Internet]. 2012[cited 2017 Jul 10];20(3):[10 telas]. Available from: http://www.scielo.br/pdf/rlae/v20n3/pt_a26v20n3.pdf

25. Edwards A, Pang N, Shiu V, Chan C. The understanding of spirituality and the potential role of spiritual care in end-of-life and palliative care: a meta-study of qualitative research. Palliat Med [Internet]. 2010 [cited 2017 Feb 28];24(8):753-70. Available from: https://www.ncbi.nlm.nih.gov/pubmed/20659977

26. Park CL, Masters KS, Salsman JM, Wachholtz A, Clements AD, Salmoirago-Blotcher E, et al. Advancing our understanding of religion and spirituality in the context of behavioral medicine. J Behav Med [Internet]. 2017 [cited 2017 Feb 28];40(1):39-51. Available from: https://www.ncbi.nlm.nih.gov/pubmed/27342616

27. Bovero A, Leombruni P, Miniotti M, Torta R. Religiosity, pain and depression in advanced cancer patients. World Cult Psychiatry Res Rev [Internet]. 2012 [cited 2017 Jul 10];8(1):51-9. Available from: http://www.wcprr.org/wp-content/uploads/2014/ 04/2013.01.51-59.pdf

28. Zhang B, Nilsson ME, Prigerson HG. Factors important to patients' quality of life at the end of life. Arch Intern Med [Internet]. 2012 [cited 2017 Jul 10];172(15):1133-42. Available from: http://www.ncbi.nlm.nih.gov/pmc/articles/PMC3806298/pdf/nihms514871.pdf

29. Asgeirsdottir GH, Sigurdardottir V, Gunnarsdottir S, Sigurbjörnsson E, Traustadottir R, Kelly E, et al. Spiritual well-being and quality of life among Icelanders receiving palliative care: data from Icelandic pilot-testing of a provisional measure of spiritual well-being from the European Organisation for Research and Treatment of Cancer. Eur J Cancer Care [Internet]. 2017 [cited 2017 May 09];26(2):e12394. Available from: https://www.ncbi.nlm.nih.gov/ pubmed/26443296

30. Evangelista CB, Lopes MEL, Costa SFG, Batista PSS, Batista JBV, Oliveira AMM. Palliative care and spirituality: an integrative literature review. Rev Bras Enferm [Internet]. 2016 [cited 2017 May 10];69(3):554-63. Available from: http://www.scielo.br/pdf/ reben/v69n3/en_0034-7167-reben-69-03-0591.pdf 
31. Mesquita AC, Chaves ECL, Avelino CCV, Nogueira DA, Panzini RG, Carvalho EC. A utilização do enfrentamento religioso/espiritual por pacientes com câncer em tratamento quimioterápico Rev Latino-Am Enfermagem [Internet]. 2013 [cited 2017 Jul 07];21(2). Available from: http://www.scielo.br/pdf/reben/v62n1/05.pdf

32. Higuera JC, González BL, Durbán MV, Vela MG. Atención spiritual en cuidados paliativos. Valoración y vivencia de los usuários. Med Paliat[Internet]. 2013 [cited 2017 Jul 07];20(3):93-102. Available from: http://www.elsevier.es/ es-revista-medicina-paliativa-337-articulo-atencion-espiritual-cuidados-paliativos-valoracion-S1134248X12000559

33. Araújo LP, Helmer DS, Gomes L, Fukuda CC, Freitas MH. Medo à morte e ao morrer em idosas institucionalizadas e não institucionalizadas. Acta Scient Hum Soc Sci [Internet]. 2009[cited 2017 Jul 07];31(2):213-8. Available from: https://dx.doi. org/10.4025/actascihumansoc.v31i2.6936 